\title{
気象変動に対する自律神経系の反応
}

\author{
柏木 力 \\ 気象研究所応用気象研究部 \\ 東大医学部物療内科教室
}

\section{Study of Autonomic Imballance at the Meteorological Changes by Multivariate Analysis}

\author{
By T. Kashiwagi \\ Meteorological Research Institute, Tokyo; Dep't. of Physical Therapy \& Internal Medicine, \\ School of Medicine, Tokyo University \\ (Manuscript received 31 October, 1959)
}

\begin{abstract}
Applying factor analyses, one of multivariate analyses, to tests of several biological functions, the author seeked for variation of linear transformed variates of tests when cold fronts passed through. From the previous observations on individuals, two independent components were extracted as function units. These and those components exhibited the particular mode of change during front passing as a whole. The 1st component, consisted of body temperature and heart beat interval, reduced markedly on frontal days and increased after front passing. The 2nd component, which was independent to the 1st component and refered to blood pressure, increased gradually at the course of front passing.

Since in this observation each component consisted of at least two characteristics and simultaneous changes of the constituents were amalgamated into one variate, these results bases on the multivariate method seems to explain more precisely the biological regulation mechanism than the results obtained from single characteristic.

The correlation between each component and common meteorological factors was almost negligible. To obtain significant figures between meteorological and biological processes, synthetic characteristic of cold front and other meteorological conditions should be taken into consideration.
\end{abstract}

\section{1. ま え がき}

生体は 外部環境の限りない变動飞対して独立で あることができ，常と自己の内部安定した恒常 的な状態, 所謂 Homeostasis を維持し続けてゆく ことができるといわれる。Homeostasis の実体そ のものについては既飞他の機会に和いて述べだ からここではくりかえさない。この意味の適応現 象は外部環境の微妙な 变動飞もよく促応して働ら く調節機構を介して達成されるが，その機構とし ては一般に自律神経系と内分泌系の 2 つの機能系 があげられる。前者は一般に急激な外界の変動に 対応して反応し，後者はより緩除な变動飞対応す るというよりも寧ろ，自律神経系の急速な反応の
方向と量とを規制すると考えられている22。 外部環境特に気象条件の变動飞ともなう自律神 経系の機能の变動飞 関する文献は極めて多数に昇 るであろろが, 恐らくこの両者の関連は, 凡そ気 象变動と生体变動との関連が気ずかれると同時飞 考察の対象になつたといえる。このことは自律神 経系が外界の微妙な变動に対して，よく促応する という点からすれば極めて当然の成行きであろろ が，現在までの業績の全ては，自律神経系の内部 の神経昂奮の衝撃の 頻度自体を計測することによ つてではなく，との神経衝撃が個々の器官飞伝達 されて生ずるその器官特有の機能を観測すること とよつて間接に 自律神経系の機能状態を推定する ことマ基づいている。 
従つてこの場合，生体内の個々の器官は自律神 経系飞よつて統一的飞統制されて和り，また個々 の器官の機能は，寒冷とか暑熱等の一定の外界の 変動飞基づく剌激に対して, 個々の器官の機能が 自律神経系の最奮または制止状態飞 発現するとさ れる方向の変化を，同時飞一様飞呈することが前 提とされる。たとえば寒冷と対して, 皮膚の血管 は収縮し，血流量は減少し，同時飞血圧が増加す るという反応が起るとすれば，とれらは何れす自 律神経系の機能にとつては，一定の方向に向いた 反応であるとされる。

これらの $2 つ の$ 事項を前提として, 自律神経系の 機能を考えるのが現在の状沉であるが，間接的な 推定といろ久陷を補う意味で，通常はさまざまの 多数の末梢効果器官の機能が観察の対象とされる。 その一つとして, 心理学者である M. A. Wenger が 因子分析法を自律神経系の機能の推定飞応用し たのは，一つのユニークな行き方であると考えら れるが，それは多数の測定值を数学的飞総合し， その結果から個体の自律神経機能を推測するとい う行さ方である（一般に Wenger 法と呼ばれる）。

著者は過去に拈いてこの方法に対する見解を既 飞発表したが334), 次いでこの方法を集団及び個体 の連続観察に応用した結果を基礎として，個体の 外部環境, 特飞気象条件の变動飞対する目律神経 系の反応の態度を捉ええたと考える。同時に自律 神経系の調節機構の実体を知る上飞和いて，2３ の重要な手がかりをえたと信ずるので報告する。

\section{2. 基 礎 的 事 項}

\section{A. 重心解飞よる成績}

Kendall 飞よると5), 成分分析 (Component Analysis) と因子分析 (Factor Analysis) との若 干の相違が指摘されている。しかし何れの場合も 最終の目的は変量を少数の因子の組合わせで現わ そろとする点で同一であると考えられるがら，こ こでは特に両者を区別せず，個体空間の中でテス ト・ヴエクトルの含まれる空間を定めるためと用 いた重心解と，テスト空間の中の個体点からの距 離の平方和の最小となる直線を求める最小自乗法 とよる主成分解を行つたという点だけを区別した。 最終の目的というのは, 要すると多数の变量の内, 独立のあのが幾つあるかを調べ, テストの結果の表
示をその少数の独立成分飞還元することである。 今個体を $w_{1}, w_{2}, \cdots \cdots, w_{n}$ で表わし， $n$ は十分大 きいものとする。 $x_{1 i}, x_{2 i}, \cdots \cdots, x_{p i}$ は， $i$ 番目の 個体の特性值で, $p$ 籄の变量を考元ると一般飞 $x_{c i}$ は $i$ 番目の個体 $w_{i}$ とついて測定した $c$ 番目の特性 の実測值とする。 $n$ 人について測定した $p$ 通りの 実測值は次の行列の形《配列される：行番昘はテ スト番号，列番号は個体番号である。

$$
\left[\begin{array}{cccc}
x_{11} & x_{12} & \cdots \cdots & x_{1 n} \\
x_{21} & x_{22} & \cdots \cdots & x_{2 n} \\
\cdots & \cdots & \cdots \cdots & \cdots \\
x_{p 1} & x_{p 2} & \cdots \cdots & x_{p n}
\end{array}\right]
$$

これから， $x_{k}$ の線型結合式で, $p$ より多くない $m$ 個の

$$
\zeta_{k}=\sum_{j=1}^{p} a_{j k} x_{j k} \quad(k=1,2, \cdots \cdots, m)
$$

でテストが表示できるとして，これを求める。

自律神経系の機能の解析飞この因子分析法を志 用した報告例は少なくないが，これらの資料特に 東大冲中内科で同一集団を 6 年間経続して計 6 回 の測定を行つた資料について，重心解による成䋶 を検討した結果は, 既飞発表したがか)，その要点は 凡そ次の通りである, 尚これらの文献に括いては, 変量としてほとんどすべての場合次の 7 種の測定 法を使用している，それは

1）手掌皮膚電気抵抗值，2）前膊皮膚電気抵抗 值，3）舌下温，4）心搏間隔，5）最高または最低 血圧，6）最低血圧または脈圧，7）唾液量 な招またこの場合, 次の 2 項が分析の際の予想と なつている，すなわち

1) 交感神経系と副交感神経系との 緊張度は相 殺され，その差飞相当するものが末梢効果器 官汶して有效な緊張度として表われる。

2）1）のように定義された自律神経系の機能は 全身飞一様飞作用する。

上述の資料の分析の検討の結果は 2 因子まで抽 出したとして次の通りである。

1）重心解で解いたままでは, 必ずし屯第 1 因 子としてWenger の生理的型と一致するもの はえられない。

2)重心解では, 因子軸の方向は便宜的なテス トあるいは:個体の含まれる部分空間を張る軸 の方向としてえられることを考元て，自由以 
座標軸の角変換を行うならば，因子の 2 次元 空間内に打いてそれぞれの变量ヴエクトルを 誤差範囲内で一致するように 重社合わせるこ とができる。しかも次の A，B 2 因子が独立 なものとしてえられる，すなわち A 因子は舌 下温とこれと逆相関である心搏間隔とによつ て作られ，B 因子は最低血圧とこれと背反的 な脈圧とによつて作られる。2 種の皮膚抵抗 は心搏間隔とほぼ等しい関係をすつが，な掠 第 3 因子軸と相関があつて独自の成分をもつ。 唾液量には一定の関係が存在しない。

3）従つて上の第 1 の予想はその成立が難しい。 解析してえられたところの常に, 安定な形で個 体空間の 2 次元部分空間内飞位置する 2 個の 独立な因子は，それぞれ機能単位として考え るべきであり,それらが交感神経系, 副交感神 経系の 2 系飞対応するか否かは別問題として, 最近の考え方たとえば Eppinger, Hess に対 するBergmannの批判ともよく合致する。

B. 主成分解による成績

解法は成書 ${ }^{5}$ とゆずり，その主な意味は，元来 $p$ 次元のテスト空間内に含まれる $n$ 個の個体点が 実は $m$ 次元の部分空間飞含まれていると予想して， これらの点からの距離の平方和が最小となる直線 を第 1 軸ととり，これと直交する空間内で同じ方 針で第 2 軸を定め，以下同様にして $m$ 個の軸を求 める $(p \geqq m) 。 こ れ は ~ p$ 個のテスト間の相関行列 の主軸を求めることと相当する。この固有根を大 きさの順に

$$
\lambda_{1} \geqq \lambda_{2} \geqq \lambda_{3} \geqq \cdots \cdots \geqq \lambda_{p} \geqq 0
$$

とした。跡は

$$
\lambda_{1}+\lambda_{2}+\lambda_{3}+\cdots \cdots+\lambda_{p}=p,
$$

$\lambda_{i}$ は個体点の第 $i$ 軸方向の成分の分散に相当する 加

$$
\lambda_{1} / p, \quad\left(\lambda_{1}+\lambda_{2}\right) / p, \quad\left(\lambda_{1}+\lambda_{2}+\lambda_{3}\right) / p, \cdots \cdots
$$

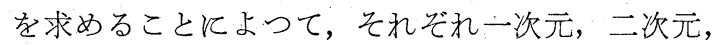
三次元，….., の部分空間だけで，全体の点のバラ ツキ方のどれくらいの割合を説明できるかを知る ことができる。

共通度を 1 ととれば，重心解は， $\lambda_{1}$ 飞対する固有 ヴェクトルとして,

$$
(1,1,1, \cdots \cdots, 1) \quad(p \text { 個の } 1)
$$

をとつたものと相当し，主成分解では，これを第 1
近似として収束するまで繰返し法で計算してえた 固有ヴェクトルになる。

図ではテスト軸方向の 単位ヴェクトルと，主軸 方向の単位ヴエクトルの内積すなわち一方のヴェ クトルの他方のヴェクトルに対する方向余弦を座 標として表示している。すすなわち第 1 軸, 第 2 軸 は $\lambda_{1} ， \lambda_{2}$ 飞相当する主軸方向で，たとえば最低血 压をあらわす点は，テスト空間で最低血化をあら わした軸の力向の 単位ヴェクトルの第 1 軸，第 2 軸への正射影を座標としている。別の言葉でいえ ば，テスト空間で最低血圧の軸の正の方向飞 1 だ け離れた点から, 主軸 1,2 の定める平面上飞下し た垂線の足に相当する点に最低血圧の交字が入れ てある。

第 1 図は東大冲沖内科の上述のデーターに対し てこの方法とよつてえた解を示してある（第 1 表， 第 2 表，第 1 図)。

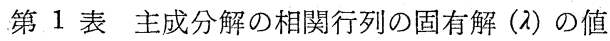

\begin{tabular}{c|cccc|c|c}
\hline 年 度 & $\lambda_{1}$ & $\lambda_{2}$ & $\lambda_{3}$ & $\lambda_{4}$ & 計 & 全説明率 \\
\hline 1951 & 1.84 & 1.49 & 1.09 & 0.87 & 5.29 & $75 \%$ \\
1952 & 1.66 & 1.51 & 1.13 & 0.89 & 5.19 & $74 \%$ \\
1953 & 1.90 & 1.66 & 0.98 & 0.89 & 5.43 & $77 \%$ \\
1954 & 2.03 & 1.51 & 1.24 & 0.82 & 5.60 & $80 \%$ \\
1955 & 1.83 & 1.57 & 1.14 & 0.85 & 5.39 & $77 \%$ \\
1956 & 1.94 & 1.46 & 1.10 & 0.97 & 5.47 & $78 \%$ \\
\hline
\end{tabular}

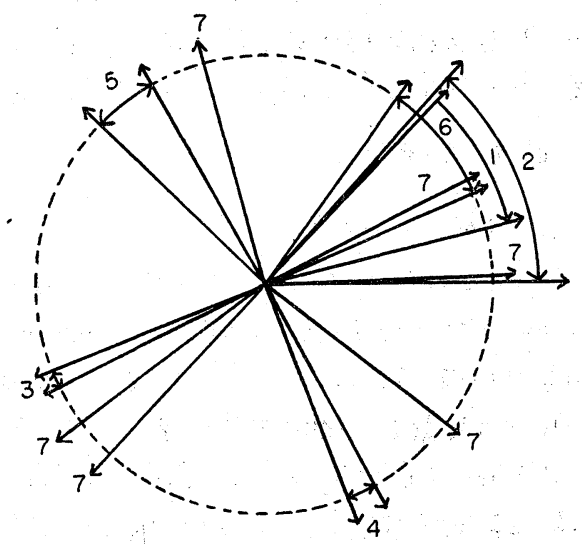

第 1 図、变量 $(1 \sim 7)$ の正規化固有ヴエクトルの方向 -6 回の繰返しの範团を示す一

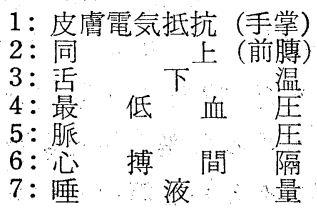

Journ. Met. Soc. Japan 
第 2 表 各変量の正規化固有ヴェクトルの值

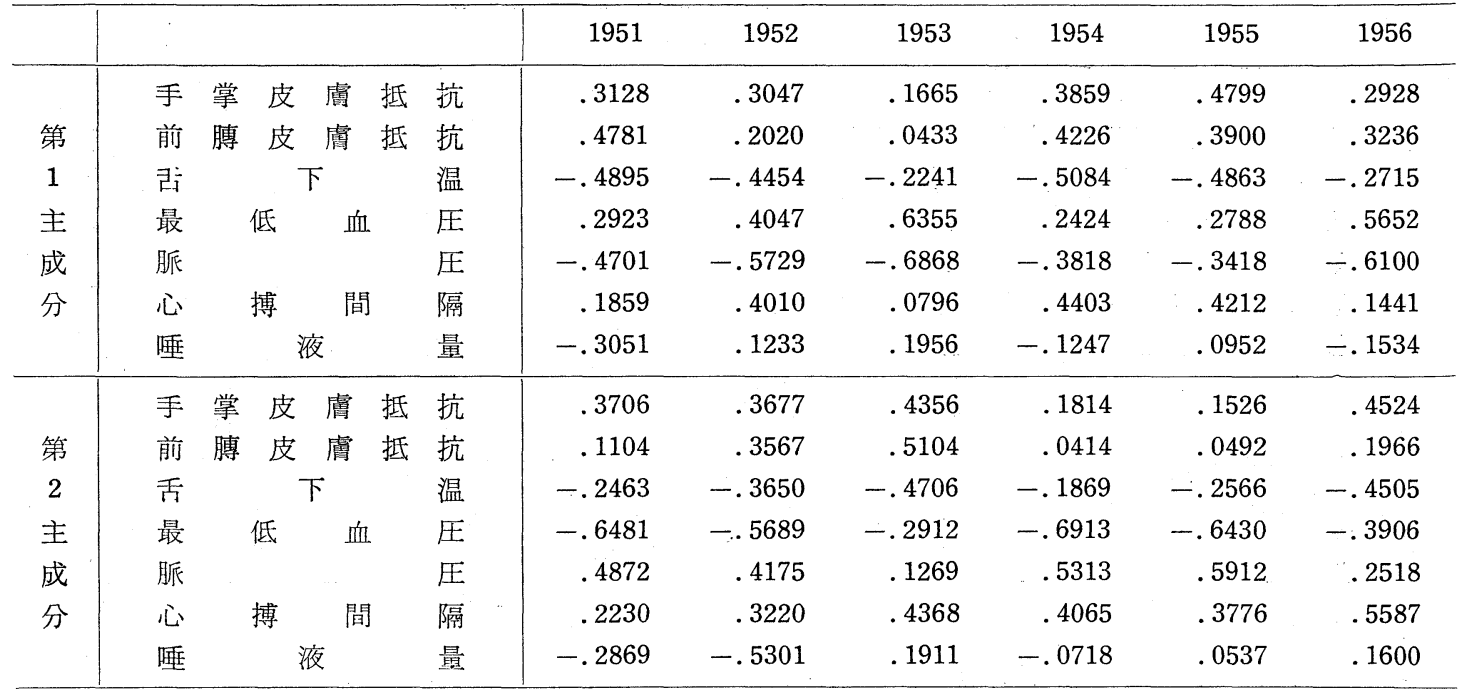

その結果，

1）第 1 , 第 2 の固有ヴエクトルの定める 2 次 元部分空間飞扮いて，座標軸の若干の回転を 行うと, 6 年間の成績は近似解である重心解飞 よるよりもよい一致を示している。

2) 前と同じようと 2 つのテスト群に対応する 直交する 2 因子がここでも認められる。すな わち最低血圧とこれと逆相関の脈圧, 舌下温 とこれと逆相関の心搏間隔, 皮膚抵抗とで定 まる 2 因子である。また脈圧は舌下温と若干 の関係をもち，乙かも心搏間隔とは直交する。

3）テスト間の相関行列の 固有解 $\lambda$ の值からす ると， $\lambda_{4}$ まで求めると全分散を説明する割合 は最高 $80 \%$ でそれ程よいとはいえない。

4）以上の変量間の独立性 ・直交性が実際江実

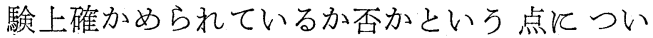
ては，たとえば皮膚の残留抵抗は従来の説に 区してアドレナリン，アトロピンで影響を受 けないといい6)，また交感神経系のみの作用を 受けるといわれる寒冷昇圧試験と皮膚抵抗と は関係がないというように，実験的事実によ つて变量間の独立性，直交性がよく支持され ている。

5) このような観点から，Aの舌下温・心搏間隔 の因子が副交感神経緊張度を，B の最低血圧・ 脈圧因子が 交感神経緊張度をあらわすという 仮説が一応成立つ可能性が生れた。
6) A，B 両因子が具体的飞何と対応していよう と，人体を集団的飞解察した場合に，これら の生体機能の調節水準の 相関性と独立性と飞 よつて, 1つの機能単位が把握される。それて よつて 個体の特性を機能単位とよつてあらわ される 2 次元空間内で位置づけることができ ると同時飞, 機能単位と外界の 物理的変化と の対応が 個々の变量をとり上げるよりは，ょ り根源的であると考兄られる。

7）局所性の強い変量は因子軸に一定の傾度を あつてあらわされるであろう。皮膚抵抗のヴ エクトルはそのことを意味すると考光てよい。

\section{20 個の変量の成績の検討}

M.A. Wenger は 6 才から 10 才までの学童 62 人を対象として 20 種の機能測定法を行ない，その データーについて重心解を行ない，結果として 2 つの主要な因子を抽出し，一因子が自律神経機能 を，他の因子が骨骼筋の胎緩性を代表し，同時飞 一つの単独な因子炕より自律神経系の 緊張度があ らわされるという点から, Eppinger, Hess の二 元拮抗支配の理論を立証したと述べている7)。著者 はこのデーターを改ためて 主成分解によつて分析 し，变量間の直交性の有無を検討した（第 3 表）。

それによると，固有ヴェクトルの大きさからは 前述の直交性を全面的浔認めることは困難であり， 20 種の变量は部分的な束を作つているとすぎない。 固有值 $\lambda_{5}$ まで求めてみても，それとよつて説明さ 
第 3 表 Wenger の 20 種の変量の主成分解

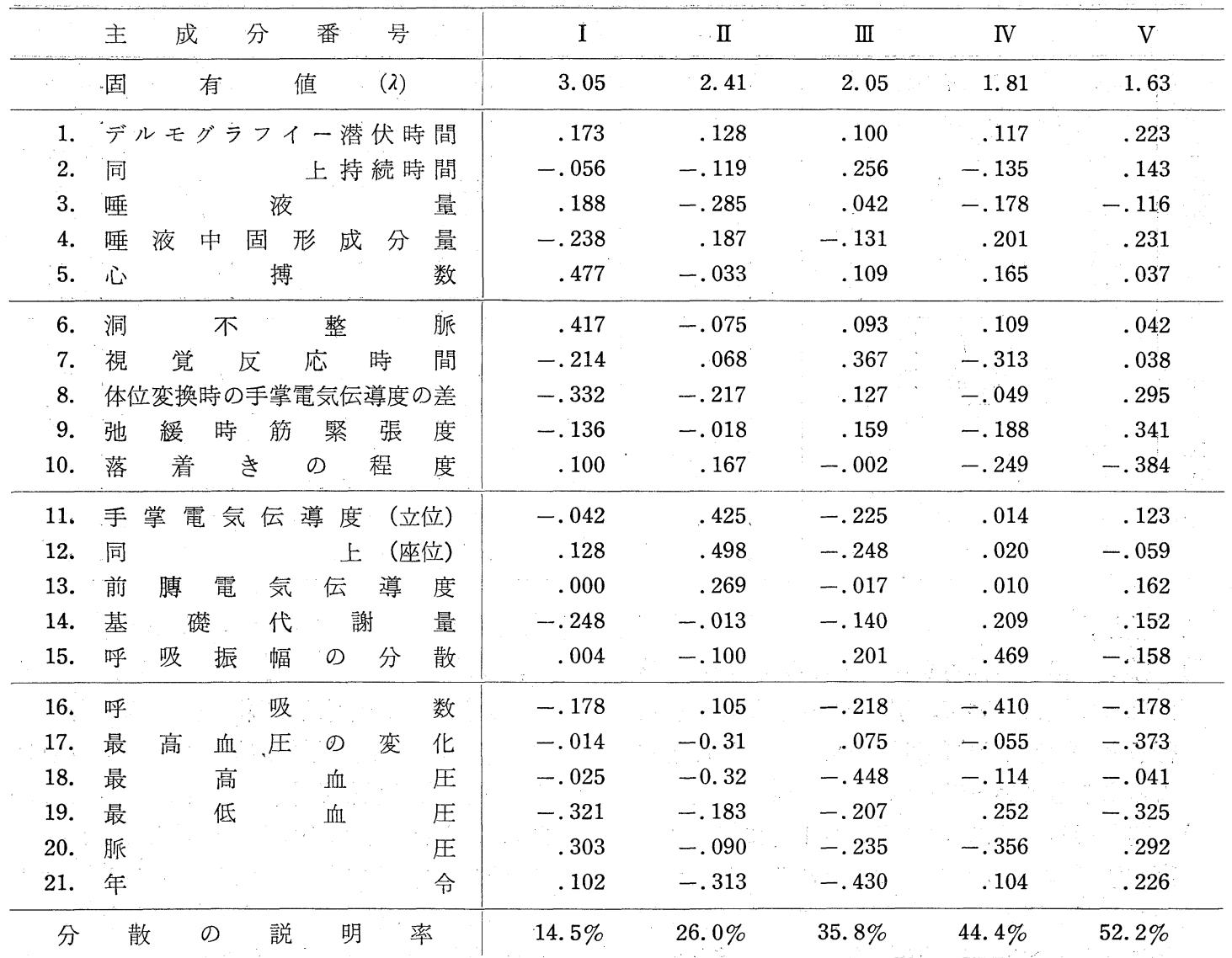

れる変動は全変動飞対して約 $50 \%$ であつて, 残差 変動として $50 \%$ がな招存在する。また $\lambda_{1}, \lambda_{2}, \cdots \cdots$, が 0 と有意㵋つているかどうかの吟味もいる。

しかし何れとせよ,因子分析の妙味は,一見相異な るテストの中から，少数の根元的な困子を探し出 すことにあるので，単飞入を大きくするだけなら， 相関の大きいもの代けと限定すればよいであろう。

Wenger が個体の全体を支配する Eppinger， Hess 型の自律神経緊張度と考えたものは，主とし て循環系関係する第 1 の成分にすぎないよろで あり，事実それによつて説明される率は $14.6 \%$ 亿 すぎない。従つて Wenger のデーターは必らずし も充分生体の調節機構一般を 解明する資料となる ことを期待しうる程の結果は示していない。

\section{3. 気象変動に対する自律神経系の反応}

自律神経系の気象条件対する 反応のありさま は，最初に述べたようと生体と、気象变化との関連
が注目されると同時飞 観察されてきたであらう。 特飞寒冷, 暑熱等の気温条件, 高空, 高山あるい は潜函江招ける気圧条件等の個々の気象要素との 関連はしばしば観察の対象となつた。

しかしこの場合常に作用因として問題になるの は個々の気象要素ではなく，その全的な複合であ る8)。たと光ば所謂気象病の発現をとつてみても， それは個々の気象要素の変動からは説明されない で, 体系的な気象条件の変化が常汇問題とされる。 生体内部の恒常的な状態，すなわち Homeostasis 維持に扮ける重要な担い手である 自律神経系の調 節過程がこの際注目されたのは極めて自然の成行 きである。そのくわしい考察は他の文献9) 飞ゆず るとして，この場合のとりあげ方は単純な薬物試 験の成績に依存しているか ${ }^{10)}$ ，併列的なとりあげ 方をして, Eppinger, Hess 流の正副交感神経系の 図式的な対比を行なろかであつで ${ }^{11)}$ ，機能単位の 反対という考え方は未だみられない。 
強いて挙げれば, Kerdö が脈搏数と最低血圧の 比 $d / p$ をとり, 自律神経係数 V.I. $=100\left(1-\frac{d}{p}\right)$ が温䁔前線通過時または通過後增加すると述べて

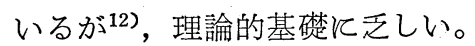

著者は前章基礎的事実飞従つて，A，B 両因子を 形成する 4 種の变量, すなわち最高・最低血圧, 心搏数及び体温（腕窩温）を測定項目として選び, 東大物療内科入院の 結核患者 8 人につき， 1 日 1

第 4 表 個体飞扮ける因子負荷量

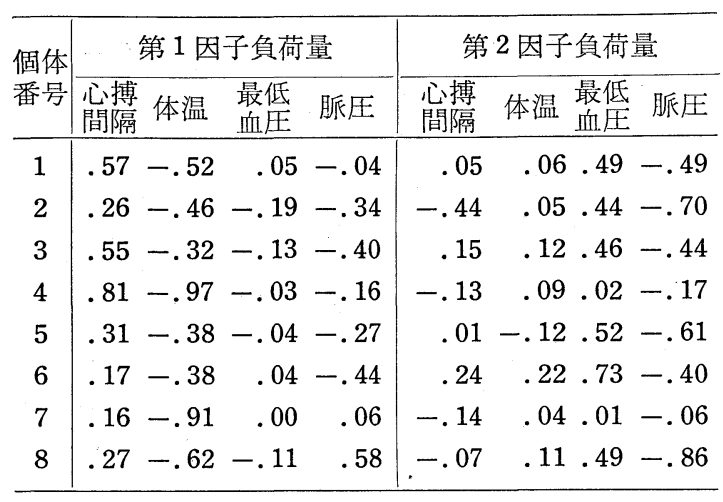

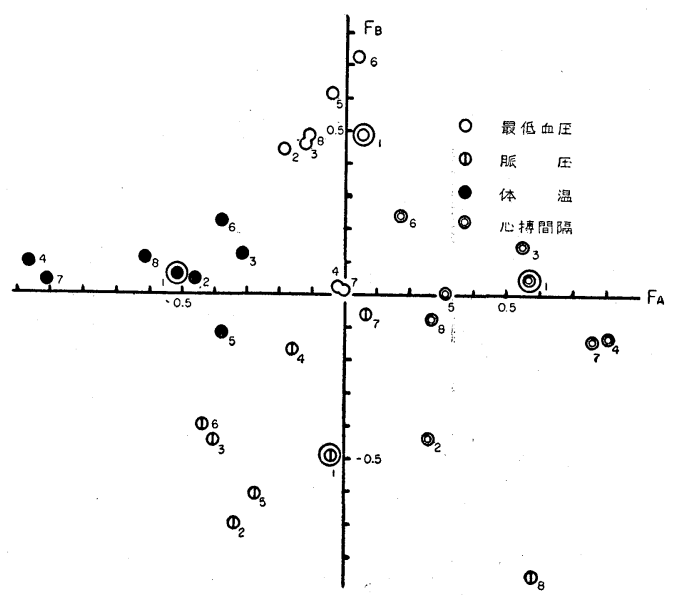

第 2 図 同一個体に拈ける因子分析
回ほぼ同時刻飞測定を行ない，100１60 日間連続 観測を行なつた。分析に当つては最低血圧, 脈圧, 心搏数の逆数及び体温に变換した。同一個体の連 日の 4 個の測定值から測定法間の相関係数を計算 し, 計算上の便宜から 重心解の変法を用いて, 解 をえた。同一個体と扮ける因子分析の結果は，第 4 表，第 2 図に示す通りである。

この場合飞も， A, B 両因子の直交性は基本的飞 は失われていないと考えられる。特に図にみるよ うと番号 1 の個体はほとんど完全淔交性を保つ ている。この事実飞もどづいて，A，B両因子とい う独立な機能単位に著目して, その量的変動を観 察の目的とした。

すなわち因子 $\mathrm{A}$ 及び $\mathrm{B}$ の量，すなわち因子得点 $F_{A}$ 及び $F_{B}$ を毎日の測定值から導く。近似的にこ れらは先の $\zeta_{1} ， \zeta_{2}$ 飞相当するものである。その計 算法は既に述べた ${ }^{13)}$ 。

対象として第 2 図での個体番号 1 を用いた。こ の個体では両因子の直交性が極めてよく保持され て拉り，集団的炕安定な構造と認められた機構を 1 個体の中保ち, 反映していると思われるので, この個体を対象とすることの意義が充分に大きく， また結果の一般性が保証されると思われる。

$F_{A}, F_{B}$ を計算するための式は次の通りである。

$$
F_{A}=-0.08607 X+0.02651 Y-0.21071 Z
$$
$+0.83469 W$

$$
F_{B}=0.40944 X-0.25114 Y+0.03145 Z
$$
$+0.05870 W$

ここで, $X$ は最低血圧, $Y$ は脈圧, $Z$ は体温, $W$ は心搏間隔の実測值の正規基準化した 值である。 従つて $F_{A}$ はほとんど体温と心搏間隔との大きさ とより決定され， $F_{B}$ は逆飞最低血圧と脈圧との变 動とより左右されることがわかる。

\begin{tabular}{|c|c|c|c|c|c|c|c|c|c|c|c|}
\hline & & & $-4^{\text {通 }}$ & -3 & 過 -2 & ${ }^{\text {前 }}-1$ & 当 ${ }_{0}^{\text {日 }}$ & $1^{\text {通 }}$ & 2 & 3 & 後 4 日 \\
\hline$F_{A}$ & \multicolumn{2}{|c|}{ （体温～心搏間隔成分） } & -.119 & -.164 & -.237 & -.055 & -.284 & -.099 & -.092 & -.133 & -.085 \\
\hline$F_{E}$ & \multicolumn{2}{|c|}{ （最低血圧～脈圧成分） } & -.094 & -.094 & .664 & .007 & .042 & .035 & .123 & .084 & .044 \\
\hline 気 & 圧 & $(x / 10+1000) \mathrm{mb}$ & 128.6 & 141.2 & 161.2 & 130.0 & 107.7 & 147.3 & 149.1 & 140.5 & 136.3 \\
\hline 気 & 温 & $10 x^{\circ} \mathrm{C}$ & 108.7 & 107.0 & 108.5 & 108.9 & 120.0 & 107.6 & 106.2 & 112.6 & 116.3 \\
\hline \multicolumn{2}{|c|}{ 水蒸気張力 } & $10 x \mathrm{mb}$ & 105.4 & 98.5 & 102.5 & 112.1 & 110.7 & 93.0 & 102.0 & 110.1 & 109.4 \\
\hline 風 & 速 & $10 x \mathrm{~m} / \mathrm{s}$ & 42.9 & 40.8 & 37.1 & 39.6 & 38.1 & 41.5 & 38.9 & 37.3 & 41.9 \\
\hline
\end{tabular}

第 5 表 寒冷前線通過時に扮ける生体機能単位の変動（時間 $N$ 法） 

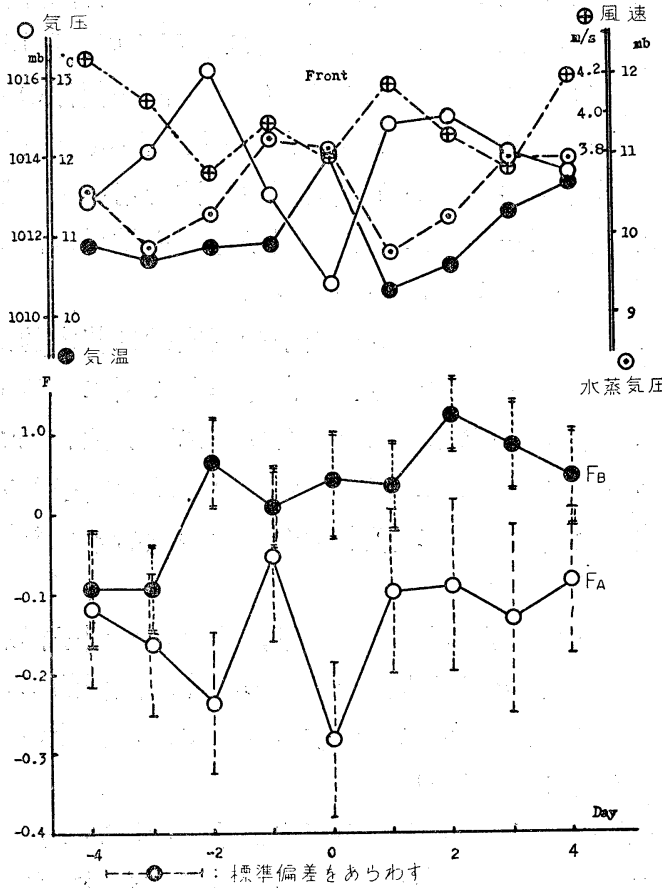

第 3 図 時 間 $\mathrm{N}$ 法

每日の $F_{A}, F_{B}$ の変動をとの日の気象条件と対応 させ，また気象条件の变動を寒冷前線の通過飞よ り整理し，時間 $N$ 法 ${ }^{14)}$ により $F_{A}, F_{B}$ の值を配 列すると, 寒冷前線通過前後の $F_{A}, F_{B}$ の量的変 動が求まる。160. 日間の钼察期間中，寒冷前線の 通過は，印刷天気団飞より決定し，全体で 46 回で あつた (第 5 表, 第 3 図)。また 4 種の気象要素, すなわち気压, 気温, 水蒸気張力及び風速の変動 と $F_{A}, F_{B}$ の変動との関連を求めた（第 4 図，第

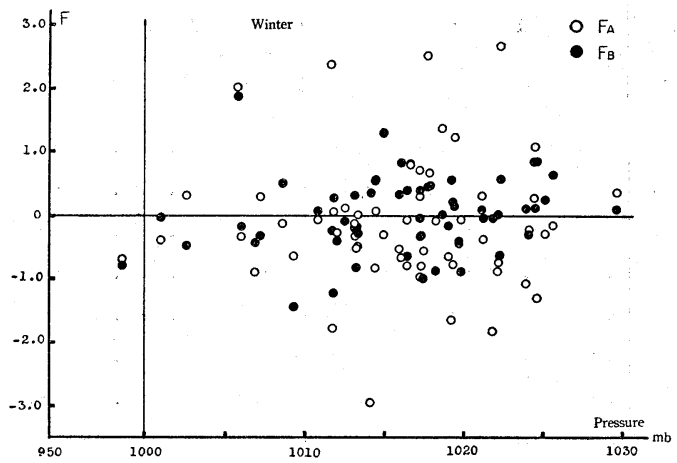

第 4 図 因子負荷量と気圧との関連
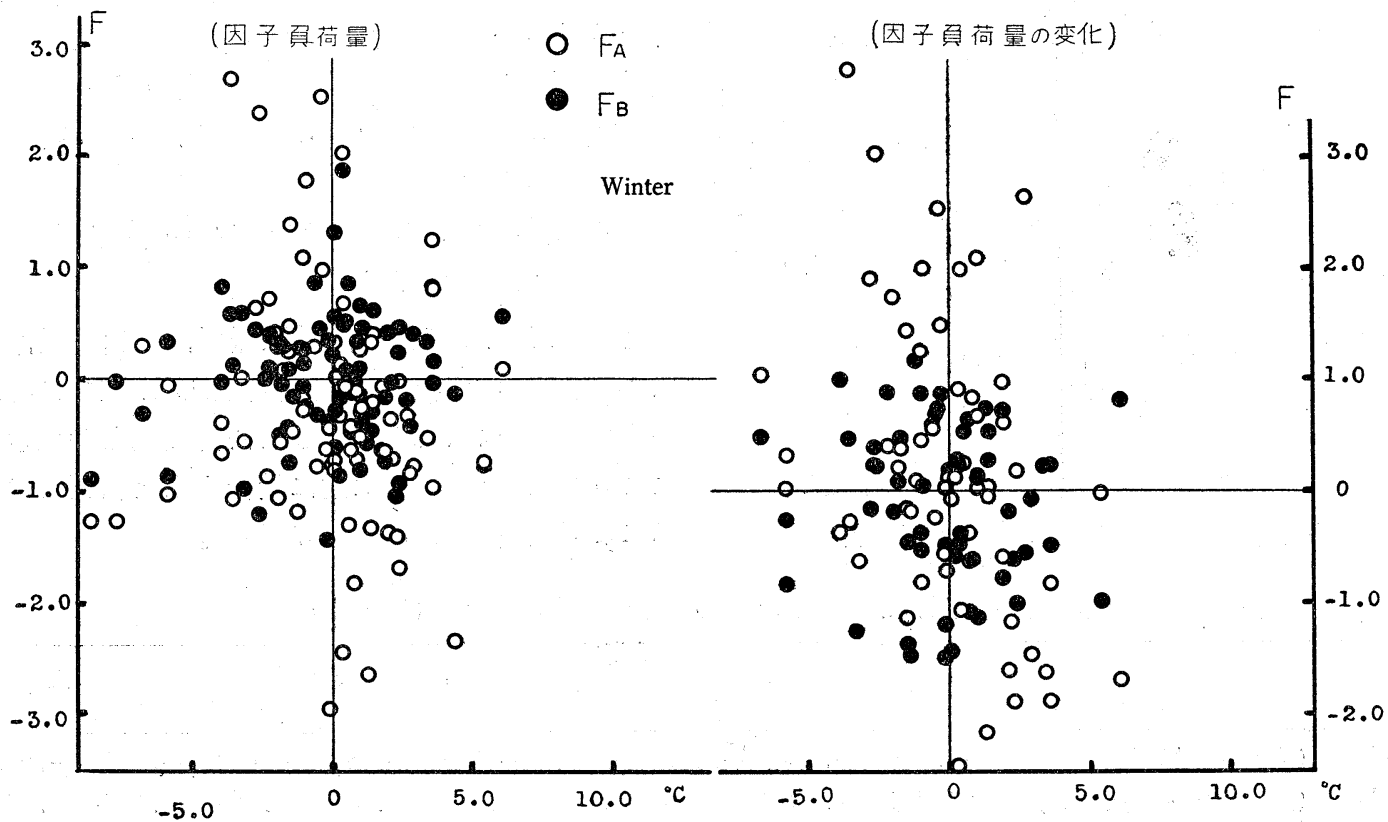

第 5 図因子負荷量と気温との関連

5 図)。同時に $F_{A}, F_{B}$ の毎日の変動を相関図にあ 無関係に 变動するものであるかどうかを確かめた らわし，2個の独立な機能単位が実際にに相互に (第6図)。 


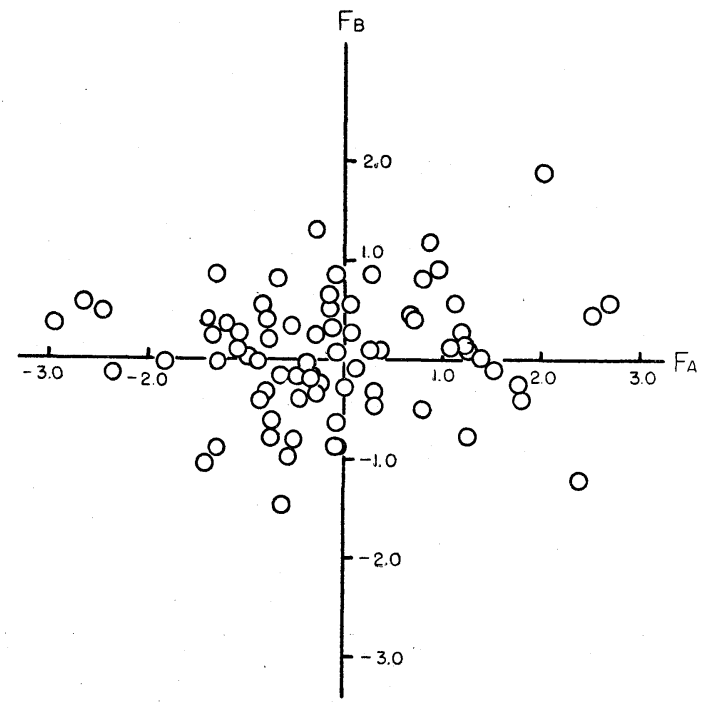

第 6 図 2 因子の变動の独立性

結果は次の通りである。

1) $F_{A}$ の寒冷前線通過飞対する反応は, 通過前 漸減し，1 日前飞急激飞増加するが通過当日 著しく低下し，通過後急增して安定した高值 をとる。この因子は体温と心搏間隔とで合成 される量であり，計算式からわかるように， 心搏間隔を増大し, 同時飞体温の低下を来し た時には合成された值は増加し，逆に心搏間 隔の減少と体温上昇とがある場合は, この值 は減少する。従つて寒冷前線の通過前には $\mathrm{A}$ 因子は体温上昇之頻脈とが次第に著しくなる よう飞動き, 一日前飞一時的飞著しい体温の 降下と心搏間隔の増加とを来すよろに働らき, 当日の急激な体温上昇と頻脈, 通過後の時期 には一定の高さまでの体温の低下と心搏間隔 の増加とを起させる。

2) 他方 $F_{B}$ は通過前から後にかけて漸増する。 この因子は最低血王と脈压とで構成されてい て, 脈王の減少と最低血圧の上昇とを来した 時には, 合成された值は増加し, 最低血压が 低下し，同時飞脈圼が増大した時には，その 值は減少する。それ故, 寒冷前線の通過時, 最低血圧を次第飞高め. 脈压を次第飞小さく するような因子が働らく。

3) $F_{A}, F_{B}$ を同時飞観察すると, 寒冷前線の通 過という要因対して, その経過と拴いて全
く無関係飞 推移しているとい方るが，通過の 近傍飞扮いては, ちよろど相反する方向飞変 動しているようとみ兄る。

4) 第 6 図とみるようと, $F_{A}, F_{B}$ の変動は相互 飞無関係であり,ここでは相関俰数は 0 であ る。すなわちすべての日を通じて両因子は独 立性を保つているとい光よう。

5) $F_{A}, F_{B}$ の值と個々の気象要素との関遭はほ とえど認められない。強いて挙げれば，第 4 図の気压と $F_{B}$, 第 5 図の気温と $F_{A}$ との逆相 関がうかがわれるが，これとても極く僅かの 相関であつて, $F_{A}, F_{B}$ の值の変動を個々の気 象要素の变動から説明することは困難である。 以上の結果飞ついて, 若干の考察を加光ると,

1）従来一般飞いわれていることは，自律神経 系の機能は寒冷前線の通過前飞は, 副交感神 経緊張状態, 通過後は交感神経緊張状態とい ろことである。著者の元た結果は, 自律神経 系の緊張状態の意味する内容飞和いては, 従 来の知見と矛循しないが，著者の意図する所 は，そのような 2 つの系の緊張状態の単なる 交替現象飞終るのではない。

また従来の個々の機能の併列的な記載を行 ろのではなくて，機能単位としての独立な 2 因子の系統的な反応をあらわしているのであ る。

2）両機能単位が相互飞独立飞変動していると いうことは, 外部環境の変動の中にあつて,

Homeostasis の保たれている個体では，少く とも基本的な 2 個の独立な機能単位という構 造が常飞 安定していることを意味している。 この場合の自律神経機能の変動は, 単飞両因 子の量的変動のみであり, 質的飞 異質の変動 ではない。眓の上からい光ば, 両直交軸上の 変動を行うだけであつて, 両因子の直交性を 破壊するものではない。

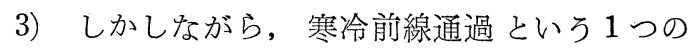
ストレスに対して，ストレスの加わる近傍に おいて両因子が相反する方向飞動いているよ うと思われることについては, 一般飞動物に アドレナリン静注後徐脈が 共軛反応として起 ることが知られて特り，乙かもこの共䡉反応 とは一定の閾値のあることも知られて拉り， 
寒冷前線の通過というストレスもこの閾値内 の效果を及ぼす程度のものであるかも知れな い。

1) 第 2 図にみられるように，血圧飞関する因 子が体温心搏間隔の因子と若干の関連をもつ ことは，血圧系が体内の熱の産生と相関をも つことを示しているのかも知れない。

な抗こことりあげたのは，4個の変量である が，渡辺飞よればメニエール氏病の場合飞も2つ の独立な因子が分離され，な扮かつ他の变量，す なわち瞳孔径, 眼裂幅, 眼圧, アシニネル反応が 体温〜心搏間隔の因子と同じ機能単位に 含まれる ことが示されている15)。

\section{4. 考察}

著者は気象変動とよつて生体の受けるひずみを 調整する.過程で 重要な役割を果す自律神経系の, 寒冷前線の通過飞対する反応を，多变量解析によ つて一部明らかとしたと考光る。

しかし生理学, 医学自体の問題としても, 自律 神経系の機能状態という概念は今日な称極めてあ いまいである。極端といえば果して自律神経系に 固有の機能状態が 考えられるかどうかも疑わしく なる。とれは間脳や中脳と存在する自律中枢に発 する神経衝撃の頻度を以て最む直接的な自律神経 機能と考えるとしても，実はその頻度も二次中枢 である神経節と扣ける神経衝揧伝達物質であるア セチルコリンやノルアドレナリンの局所的な濃度, 末梢の個々の效果器官の感受性飞左右されるであ ろう。このよう考旮ればむしろアセチルコリン やノルアドレナリンの神経末端の分泌効率, コリ ソェステラーゼやモノアミンオキシダーゼのよう な衝撃伝達物質の分解酵素能などの 綜合された上 での末梢器官の活動性こそが一次的な意義を持つ ていて，自律中枢飞発する衝撃の頻度という概念 はこれらの諸要因の従属的な役割を持つとすぎな くなる。神経衝撃の頻度として定義される自律神 経の機能状態は，末梢の交感神経飞ついては最近 その電気的な特性を誘導し記録することに成功し たといろ報告 ${ }^{16)}$ があるが，中枢性の衝撃について は未だ測定されたことがなく，また外部環境の変 化対して Homeostatis を維持することを目的と する微細な 調節のためそ有效なのは，そうした中
枢性の機能状態ではなくて, 末梢の実効器官の活 動状態であることを考えると，中枢性の神経衝撃

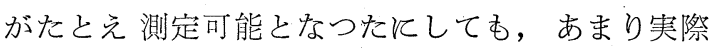
の役には立ちそうにもないであろう。

仮りにこの基本的概念が何等かの形で解決され たとしても，Eppinger, Hess のいうような自律神 経系の 2 つ分肢である 交感神経系と副交感神経 系の二元的，拮抗的支配の説，それがアドレナリ ソ, ピロカルピン，アトロピソ等の薬物によつて 惹起される体内の状態と一定の 対応をむつという 理論17)は，何等の実証を経ることなしと導入され た概念である。

また G. v. Bergmann が指摘した Eppinger, Hess の模型的理論飞対する理論 ${ }^{18}$ は, 一般に自律 神経系の不安定状態を考える点でより現実に近ず いているといえようが，な招未解決の間題が残る。

というのは, Bergmann の考方方は固有の自律 神経系の機能を必ずしも重視して拉らず, “未梢器 官の反応態度は自律神経系飞よつてのみ支配され るのではなく，器官自身及び自律中枢から末梢に 到る全自律神経系は体液的飞支配され，体液性調 節機構を神経性調節機構の上位飞招き，前者は後 者を強く条件ずけるものであるとする。

更にまた，自律神経系の支配が全身に一様 に行 われるのか， あるいはただ局所的にのみ行われる のかという点ああいまいである。交感神経系の支 配及び副交感神経系飞属する迷走神経 の支配はほ ぼ相匹敵する程度に全身的であるといえてむ，そ の他の副交感神経系の支配は局在的であるとする 考方方が強い19)。そ弓であるならば，自律神経系 の機能のあいまいさは，ますますとの度を強め， 機能測定の面飞捻いても大いな混乱が生じよう。 何礼として自律神経系の一部の局在的な支配と いうことは，個体の特性值としての自律神経系の 機能状態の統一的な理解をさまたげる。

以上述べた点から自律神経系及びその機能測定 法が当面している問題は，

1) 自律神経系の 機能状態を条件ずける要因は 単独ではなく, 神経衝撃伝達物質の分泌速度, その分布状態及びそれらの物質の分解速度, 末梢効果器の感受性が影響を及ぼしている。

2）系全体は，常に諸種の電解質やホルモンを 含む体液によつて反応の準備状態を形成され 
ていると考えられる20)。

3）調節機棈の構造。

4）アセチルコリンという分解速度の早い物質 によつて伝達される副交感神経系の全身的な 支配の程度。

5）自律神経系の最良の機能測定法は何のよう な形のものであるか。換言すれば，全身のす べての器官飞分布している自律神経系の機能 状態を充分よく反映するためとは，何れだけ のものを計測対象として取り上げなければな らないか。またどのような方法によつて多数 の測定值を綜合するかという問題。

6）5）と関連して一個体の自律神経系の機能は どのような形で数量化され，把握されるか, そのような数量化は実際上の目的，使用にた えるかという点。

著者はこのような点から現在あいまいなままに 考えられている個体の特性值としての自律神経緊 張度という概念が，著者のいろ機能単位を以てす ればその量として把握することができ，それにす とずいて気象条件の変化飞対する反応性の一つの 把え方結果とを確立したと考光る。

な扮個々の気象要素と，綜合された因子の量と の相関が無視しろる程のものであるということは， 当然であつて，この場合気象条件の変動の側飞拉 いても，個々の要素の綜合が行われ，それによつ て同時飞個々のものの独立性の存在の有無を確め る必要があると思われる。それとよりたとえば気 象前線の綜合的な量的把握, 強度の類別が行われ よう。

終りに, 東大大島教授の御指導と御校閲, 気象 研究所応用気象研究部長 伊東殭自博士, 同室長増 山元三郎博士, 並び飞東大高橋㘢正博士の御助言 飞謝意を表する。また資料の面で御協力を頂いた 東大冲中教授飞深謝するとともに，計算の便宜を 供与された文部省統計数理研究所橴谷政昭氏飞感 謝する。

\section{要 約}

多变量解析の一つである因子分析法を多くの生 体機能の測定值飞適用して，それらの綜合した值 の，寒冷前線の通過飞ともなら变動を求めた。あ らかじめ集団観察及び同一個体と抢ける長期連続
観察から，7 種の生体機能の中から少くとも 2 箇 の独立成分が抽出されることを確め, その各々の 成分飞ついて変化過程を求めた。

第 1 の成分は体温と心搏間隔とから構成され, この成分は前線の通過時の一時的な減少と通過後 の增加とを示す。これと独立な第 2 の成分は血圧 飞関する成分で, この成分は前線の通過の過程 に 従つて持続的飞增加する。

ここでは各々の成分はとれぞれ 2 籄の実測值を 構成分として含んで扔り，その構成の同時的な変 化が一定の weight をつけられて線型結合された 值の变動として表わされるから，個々の実測值を 問題飞するよりは遙か飞生体の外部環境飞対する 調節機構の実情に近ずいていると考えられる。同 時飞実質的な意味飞招いて自律神経系の機能飞対 して,より尤むらしい推定值を与えると考えられ る。

$2 つ の$ 独立な成分の变動と個々の気象要素との 相関はほとんど認められない。有意な相関を求め るためとは，前線を含めて気象条件の变動の綜合 的な特性值がやはり考无られなければならないだ ろう。

\section{文献}

1) 柏木 力, 增山元三郎, 鳥居敏雄, 1952: 気象医 学 病態生理学大系, $3,186$.

2)柏木力, 1959：気象現象济するとトの反応性 飞ついて, 天気, $6,220$.

3）高橋晄正, 柏木 力, 1957 : 因子分析飞よる現象 解析, 日新医学, 44, 295.

4) 高橋惓正, 柏木力, 葛谷信貞ほか, 1959: Wenger の自律神経緊張度測定法飞和ける独立な 2 因子飞 ついて。日新医学, 46, 135.

5) Kendall, M. G., 1957: A Course in Multivariate Analysis, 10.

6) 冲中重雄 et al., 1959：皮膚䉓気抵抗測定法とそ の応用, 自律神経機能検査法飞関する留談会予稿 集, 14.

7) Wenger, M. G., 1942: A Study of Physiological Factor. Human Biology, 14, 69.

8）増山元三郎, 1942 : 低気圧の通過と人体の変調, 科学 12,118 .

9) 柏木 力, 增山元三郎, 鳥居敏雄, 1952: ibid.

10）小川静男, 1948: 気象の肺結核飞及ぼす影響 (III), 前線通過の患者自律神経系に及ぼす影響, 医学々生 物学, $15,237$.

11) Curry, M., 1951: Klimaunterschiede und wetterbedingte Reaktionstypen. Med. Meteorol. Hefte, 5, 39. 
12) Kerdö, I., 1958: Eine neue Untersuchungsmethode zur Einfassung der Veräuderungen der Vegetativen Reaksionslage unter dem Einfluss Meteorologischer Faktoren, Intern. J. Bioclimatol. \& Biometeorol. 2.

13）鳥居敏雄, 高橋晄正, 柏木 力, 1952 : 肝機能の 分析と総合, 最新医学, 7, 138.

14）増山元三郎, 1941：生物気候学に打けるェヌ法に ついて, その一般公式化と誤差判定法, 日本温泉気 候学会誌, 6, 439 .

15）渡辺勈, 1959：メニエール氏症候群に沶ける左
右差の問題, 日本耳鼻咽喉科学会第 60 回総会宿題 報告集, 15 .

16) 入内島十郎， 1959 ：自律神経の活動電位につい て，医学のあ!ゆみ, 28, 515.

17) Eppinger, H. u. Hess, L., 1909 :

Z. Klin. Med. 67, 345.

18) Bergmann, G. v., 1936: Funktionelle Pathologie, 10.

19)滰野増市，1959 :

最新医学, 14, 248.

20)柏木力, 1959: ibid. 